\title{
IMAGENS POÉTICAS E PICTÓRICAS DAS CATARATAS DO IGUAÇU E SETE QUEDAS: POESIA E MEMÓRIA
}

Antonio Donizeti da CRUZ ${ }^{1}$

\begin{abstract}
RESUMO: 0 presente artigo visa o estudo das imagens representativas das Belezas Naturais do Paraná, (re) apresentadas pelos escritores, poetas, artistas plásticos, que possibilitem uma reflexão sobre a natureza, sobre a poesia, a pintura, artes visuais, com textos representativos do Estado, bem como as confluências do sentido da arte, da linguagem poética, dos aspectos sociais, míticos e da intertextualidade presentes em imagens poéticas e picturais, fotográficas, visuais, tais como as Cataratas do Iguaçu e Sete Quedas, com estudos nas imagens simbólicas e na valorização de temas interligados às belezas naturais do Paraná, e na valorização de tais imagens presentes nas obras dos poetas, artistas, do Paraná e do Brasil.
\end{abstract}

\section{Imagens poético-aquáticas do Paraná}

Para Octavio Paz, cada civilização é uma metáfora do tempo. Já a imagem do mundo - estrutura inconsciente da sociedade -, nutrida por uma concepção particular de tempo (PAZ, 1991, p. 97) -, se alicerça nas produções culturais, por isso é que ela remete à encarnação de uma presença. É pelo diálogo com o mundo que o

${ }^{1}$ Professor Associado da Universidade Estadual do Oeste do Paraná. Bolsista Produtividade em Pesquisa pela FUNDAÇÃO ARAUCÁRIA - Paraná. 
homem se instaura frente à realidade na qual se insere, ou seja, as imagem do poema é sempre um convite à transmutação de sentido. Nesse sentido, as imagens do tempo e do mundo se interligam. 0 homem é tempo. Se cada época escolhe sua definição de homem, para Octavio Paz, a do nosso tempo é "o homem é um emissor de símbolos" (1991, p. 114).

Conforme Bachelard (1989b), a imagem ao assumir um valor cósmico produz o efeito de um pensamento vertiginoso. Uma tal imagem-pensamento, um tal pensamento-imagem-frase é uma proeza de expressão. As palavras vão além do pensamento. Toda poesia é retorno, começo. As imagens-frases que são um colorido especial, que contam as chamas vegetais são igualmente ações polêmicas. Com os poetas contemporâneos, entramos no reino da poesia brusca, poesia de ruptura, "uma poesia que não conversa, mas que sempre quer viver em primeiras palavras. Portanto, é preciso escutar os poemas como palavras ditas pela primeira vez. A poesia é admiração, exatamente ao nível da palavra, na palavra e pela palavra" (BACHELARD, 1989b, p. 79).

Em relação às forças imaginantes da nossa mente, Bachelard salienta que elas se desenvolvem em duas linhas bem diferentes. Umas encontram seu impulso na novidade; divertem-se com o pitoresco, com a variedade, com o acontecimento inesperado. A imaginação que elas vivificam tem sempre uma primavera a descrever. As outras forças imaginantes escavam o fundo do ser e, ao mesmo tempo, querem encontrar no ser, o primitivo e o eterno. Dominam a época e a história.

Para Gilbert Durand, o imaginário é "o reservatório concreto da representação humana em geral, onde se vem inscrever o trajeto reversível que, do social ao biológico, e vice-versa, informa a consciência global, a consciência humana" (2003, p. 65). A imaginação, por sua vez, é uma forma de pensamento, a qual não necessita de um processo descritivo e que se utiliza da lógica dos símbolos, isto é, a mente se utiliza de imagens quando não consegue representar de maneira direta o mundo por meio de uma percepção 
simples ou sensação, conforme assevera Durand. Salienta ainda que a imaginação se define como uma reação defensiva da natureza contra a representação da inevitabilidade da morte, por meio da inteligência. A função da imaginação é, acima de tudo,

uma função de 'eufemização', mas não é simplesmente ópio negativo, máscara que a consciência ergue diante da hedionda figura da morte, mas pelo contrário, dinamismo prospectivo que através de todas as estruturas do projeto imaginário, tenta melhorar a situação do homem no mundo. (DURAND, 1995, p. 99. Grifo do autor).

Dessa forma, a imaginação simbólica é um elemento de equilíbrio psicossocial, sociológico, psíquico e biológico. Assim, a imaginação e memória são elementos que balizam as obras dos poetas e artistas do Paraná e Brasil - ao (re)apresentarem as imagens das belezas naturais do Estado do Paraná, uma vez que elaboram uma poiesis alicerçada em um mundo de significações, com suas imagens simbólicas com as quais realizam um fazer poético e construção imaginária que remetem à condição humana e à natureza: transitoriedade e permanência. 0 conjunto dos textos poéticos e pictóricos forma uma constelação de textos-imagens que visam preservar, compartilhar os saberes e a construção de uma Memória de valorização do patrimônio do Paraná e Brasil, com vistas à interação dos contextos a partir das Belezas Naturais do Estado - Cataratas do Iguaçu e Sete Quedas - convertidas em "vozes" e "imagens" que visam compor um quadro mais amplo de uma "memória do mundo". Ou como diz o poeta e pensador Octavio Paz, "a poesia é a Memória feita imagem e esta convertida em voz. A outra voz não é a voz do além-túmulo: é a do homem que está dormindo no fundo de cada homem" (1993, p. 144. Grifo do autor).

Para o filósofo Gaston Bachelard, o homem sonha através de uma personalidade de uma memória muito antiga. Ele mira-se em seu passado, pois toda imagem para ele é lembrança. Nesse 
sentido, memória e imaginação não se deixam dissociar, ou seja, ambas trabalham para o aprofundamento mútuo. Elas constituem, na ordem dos valores, uma união da lembrança com a imagem. "Uma memória imemorial trabalha numa retaguarda do mundo. Os sonhos, os pensamentos, as lembranças formam um único tecido. A alma sonha e pensa, e depois imagina" (BACHELARD, 1993, p. 181).

Durand salienta que a memória tem "o caráter fundamental do imaginário, que é ser eufemismo, ela é também, por isso mesmo, antidestino que se ergue contra o tempo" (1997, p. 405. Grifo nosso.). É ainda "poder de organização de um todo a partir de um fragmento vivido". Essa potência "reflexógena" é "o poder da vida", que por sua vez, é capacidade de reação, de regresso. A organização que faz com que uma parte se torne "dominante" em relação a um todo é a negação da capacidade de equivalência irreversível que é o tempo. Por isso, a memória - bem como a imagem - é a magia dupla "pela qual um fragmento existencial pode resumir e simbolizar a totalidade do tempo reencontrado" (1997, p. 403). 0 ato reflexo é ontologicamente esboço da recusa fundamental da morte. Longe de estar do lado do tempo, “a memória, como o imaginário, ergue-se contra as faces do tempo e assegura ao ser, contra a dissolução do devir, a continuidade da consciência e a possibilidade de regressar, de regredir, para além das necessidades do destino" (DURAND, 1997, p. 403). Frente às "faces do tempo" e à cristalização da "memória", o homem se vê isolado, ilhado, mesmo estando rodeado por uma multidão. Mergulhado em um mundo de imagens e realidades que dão uma configuração à própria vida, ele é sabedor da sua condição existencial: a solidão habita a sua vida. Ou seja, ela é experiência viva que se concretiza não só enquanto recolhimento, mas, acima da tudo, como sentimento intrínseco frente à sensação de isolamento e vazio vivenciado pelo sujeito humano.

Para Octavio Paz, o vocábulo imagem possui múltiplas definições, entre elas um valor psicológico, pois elas são produtos do imaginário. A imagem é toda forma verbal, frase ou conjunto de frases, que o poeta diz e que interligadas entre si compõem o poema. 
Toda imagem, ou cada poema composto de imagens, enquanto "cifra da condição humana", contém um número extraordinário de significados contrários ou díspares. "Toda imagem aproxima ou conjuga realidades opostas, indiferentes ou distanciadas entre si. Isto é, submete à unidade a pluralidade do real" (PAZ, 1991, p. 120).

Os textos literários, plásticos, visuais, imagéticos dos poetas e artistas que abordam as imagens das Cataratas do Iguaçu e Sete Quedas, (imagens das belezas naturais do Paraná) são embasadas em um fazer poético e artístico centrados na força da linguagem e na concretização de um dizer que aponta para imagens visuais, momentos de observação atenta de um eu em sintonia com o mundo circundante.

\section{Cataratas do Iguaçu: a poética das águas}

Um número significativo de poetas do Paraná e do Brasil ao (re) apresentar as imagens poéticas, pictográficas, figurativas, visuais, centram suas obras em um universo poético e imaginário em que configuram espaços de lirismo, elaboração estética e construções de "mundos imaginários possíveis, com obras que apresentam o social, o mítico e as configurações centradas nos campos da imaginação e da memória. Privilegia-se, no presente projeto as imagens das belezas naturais do Paraná, com suas imagens poéticoplásticas, das Cataratas do Iguaçu e Sete Quedas, tão "cantados" e (re)apresentados pelos poetas e artistas.

O poeta Fábio Campana, em Paraíso em Chamas (2013), assim se expressa sobre as Cataratas [do Iguaçu]: 


\title{
CABEZA DE VACA
}

\author{
Dom Alvar Nuñes \\ Cabeza de Vaca \\ não achou ouro, \\ não achou prata, \\ muito menos diamante, \\ achou as Cataratas. \\ E como fazem os turistas \\ deslumbrou-se por um dia \\ e seguiu adiante, \\ deixando detrás de si \\ os estragos típicos \\ do visitante. \\ (CAMPANA, 2013, p. 63)
}

São versos que expressam a visão do eu lírico que reporta ao passado - enquanto espaços da memória - e centra o olhar na questão do deslumbramento da natureza mesmo que seja de um tempo curto, mas que segue adiante deixando as marcas do que seria os "os estragos típicos do visitante". Com o olhar voltado ao explorador Cabeza de Vaca aos turistas contemporâneos, que se não encontram ouro ou prata, se encantam com as belezas naturais das cataratas. 0 explorador espanhol Alvar Nuñez Cabeza de Vaca foi o primeiro homem branco a avistar as Cataratas do Iguaçu, em 1542, quando "se deslocava do litoral de Santa Catarina rumo a Assunção, no Paraguai, cidade recém-fundada por expedições anteriores, quando se deparou com a grandiosidade das quedas d'água." ("Cataratas do Iguaçu”, 2015).

Segundo Maurício Ragagnin Pimentel (2010), a "mesma 'falha geológica' é atribuído um sentido diverso pelo explorador Cabeza de Vaca, e hologramaticamente pela sociedade quinhentista espanhola a que este pertencia. Este, que conta-se ser o primeiro branco a relatar as quedas, lhes atribuiu uma toponímia cristã: Saltos de Santa Maria. Em sua busca pelas riquezas minerais americanas, o explorador acompanha os índios em um caminho às entranhas do 
continente, o Peabiru. Sua intencionalidade apreendia os rios como meios de navegação." (PIMENTEL, 2010. Grifo nosso).

Álvar Núñez Cabeza de Vaca foi o primeiro branco a contemplar as Cataratas do Iguaçu e também a foz [do Iguaçu]:

\begin{abstract}
Mas ao irem rio Iguaçu abaixo, era tão forte a correnteza que as canoas corriam com muita fúria. Logo adiante do ponto onde haviam embarcado o rio dá uns saltos por uns penhascos enormes e a água golpeia a terra com tanta força que de muito longe se ouve o ruído. De modo que foi necessário sair da água, tirar as canoas e conduzi-las por terra até passar aqueles saltos. Assim, à força de braços, as conduziram por mais de meia légua passando grande trabalho. Vencido aquele obstáculo, voltaram a colocar [as canoas] no [rio] Paraná. Quis Deus que a gente que ia por terra com os cavalos e os que iam por água com as canoas chegassem ao mesmo tempo. (CABEZA DE VACA, 2009, p. 125-126).
\end{abstract}

Se o desnível do rio Iguaçu, na observação do explorador foi notoriamente interpretado como "um obstáculo", os apontamentos do explorador direcionam para a observação das terras planas, boas para o cultivo. Já "as áreas silvestres, montanhas e pântanos eram tidos como os símbolos vivos do que merecia ser condenado." Em outros trechos Cabeza de Vaca (1987, p.138) narra os recursos dessa terra que parece ser "a mais fértil do mundo". A natureza era apreciada segundo sua utilidade e a capacidade do homem em dominá-la. (apud PIMENTEL, 2010).

Note-se, no poema "Cabeza de Vaca", de Campana, que ao se criar estruturas, relações, a partir de elementos preexistentes, o poeta mediante a criatividade conecta estruturas mentais, expressas mediante formas e linguagem altamente elaborada, resulta em uma construção poética alicerçada na arte-poesia. Dos golems de palavras, labirintos de imagens, águas, mármores de pedra e cores, sons ou gestos, os poeta-artistas combinam esses materiais com o intuito de "intensificar a experiência e provocar profundas emoções para distinguir certas composições de ações fluentes, distinção que 
hoje em dia é mais necessária que nunca" (RACIONERO, 1995, p. 15-16).

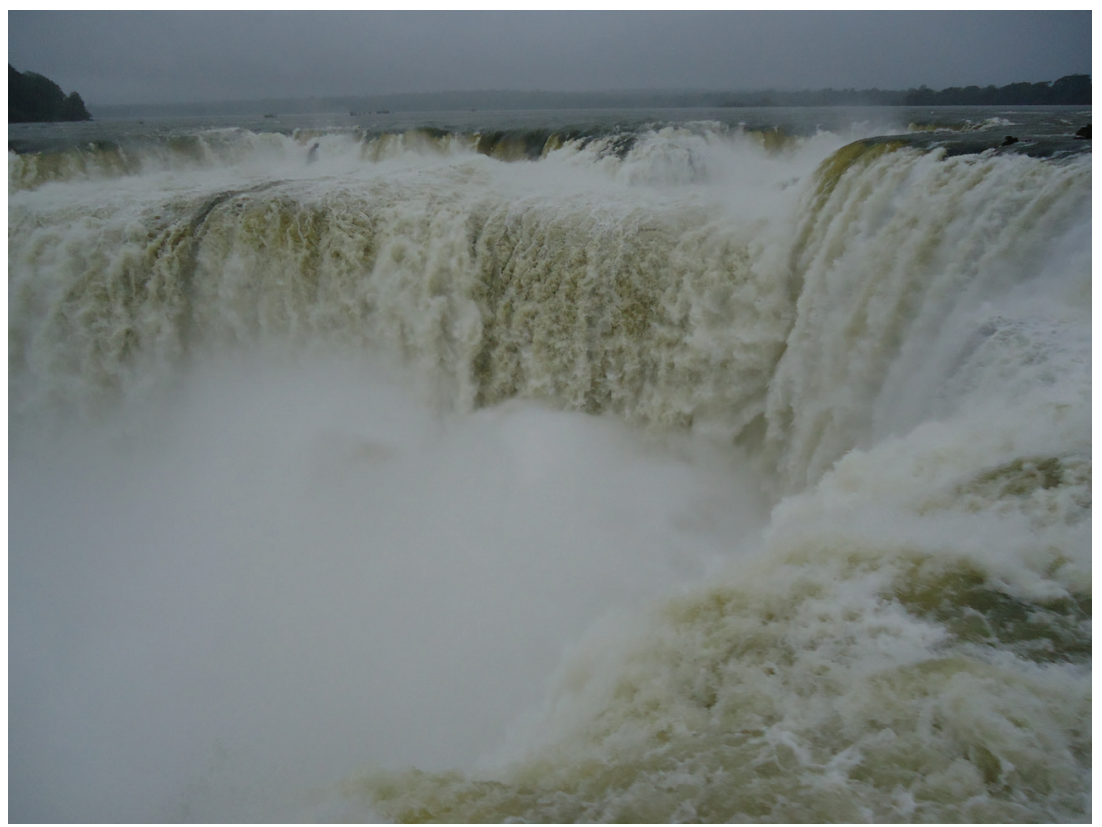

Figura 1: Garganta do Diabo - Cataratas do Iguaçu (lado argentino). Out. 2011.

Fonte: Fotografia de Antonio Donizeti da Cruz

A pintura intitulada "Cataratas do Iguaçu" (1920), do artista Frederico Lange de Morretes, mostra a vigor e a beleza de uma das mais belas paisagens da natureza: 


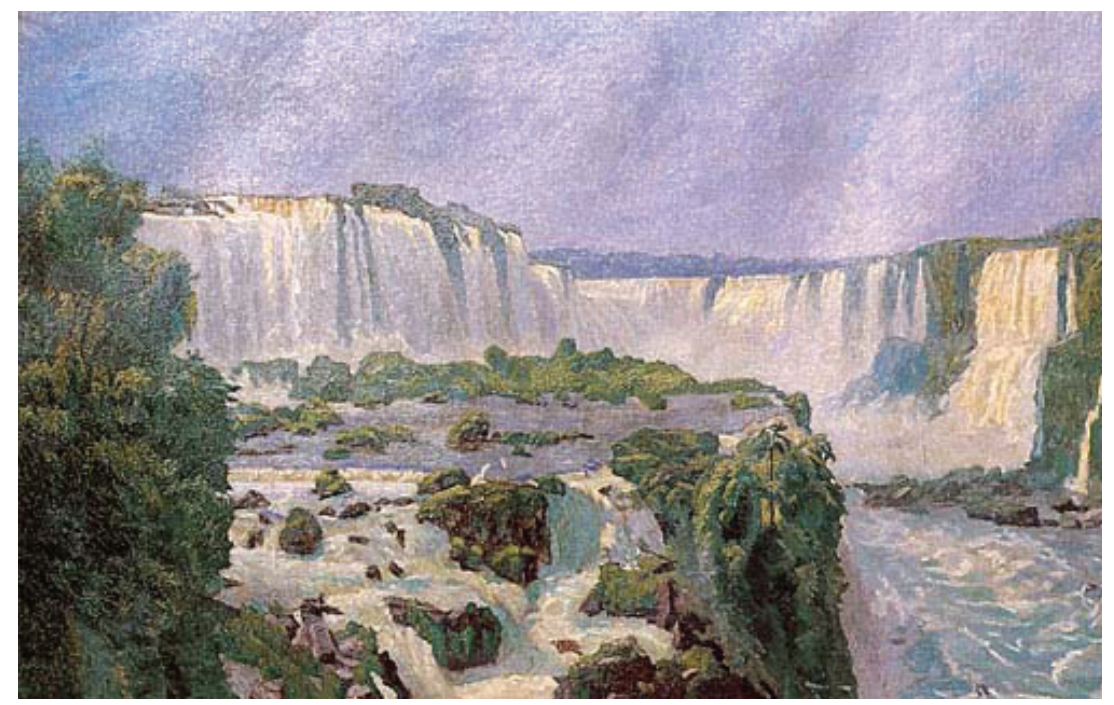

Figura 2: LANGE DE MORRETES, Frederico. - Cataratas do Iguaçu, 1920. Óleo sobre tela. 143 x 224 cm. Coleção Clube Curitibano.

Fonte: PINTORES da Paisagem Paranaense, 2005, p. 163.

A harmonia e beleza da tela apresenta o olhar de encantamento pelo quadro natural, visto pelo olhar do artista Frederico Lange (1892 - 1954), mais conhecido como Friz Lange de Morretes, foi pintor, desenhista, gravador e professor paranaense e um dos idealizadores do paranismo. Nota-se, na pintura, a vasta unidade da água, uma vez que na acepção de Bachelard, em A água e os sonhos: ensaio sobre a imaginação da matéria, "o riacho, o rio, a cascata têm, pois, um falar que os homens compreendem naturalmente. Como diz Wordsworth, "uma música da humanidade" (1989a, p. 201). Nesse sentido, em toda a atividade poética (plástica), há uma espécie de reflexo condicionado, quer se trate das raízes que reúnem impressões visuais, auditivas e vocais, justamente pelo fato de a "água tem também vozes indiretas". A natureza repercute ecos ontológicos. Os seres respondem-se imitando vozes elementares. De todos os elementos, a água é o mais "fiel 
espelho das vozes" [Tristan Tzara]." (BACHELARD, 1989a, p. 199).

O turbilhão das águas também é registrado na pintura de Antonio Diogo da Silva Parreiras (1860-1937), intitulado "Cataratas do Iguaçu", de 1920, com suas cores e pinceladas que iluminam e dão vida à tela, em que se percebe um índio contemplando as cataratas com suas águas de denso volume e o canto das águas:

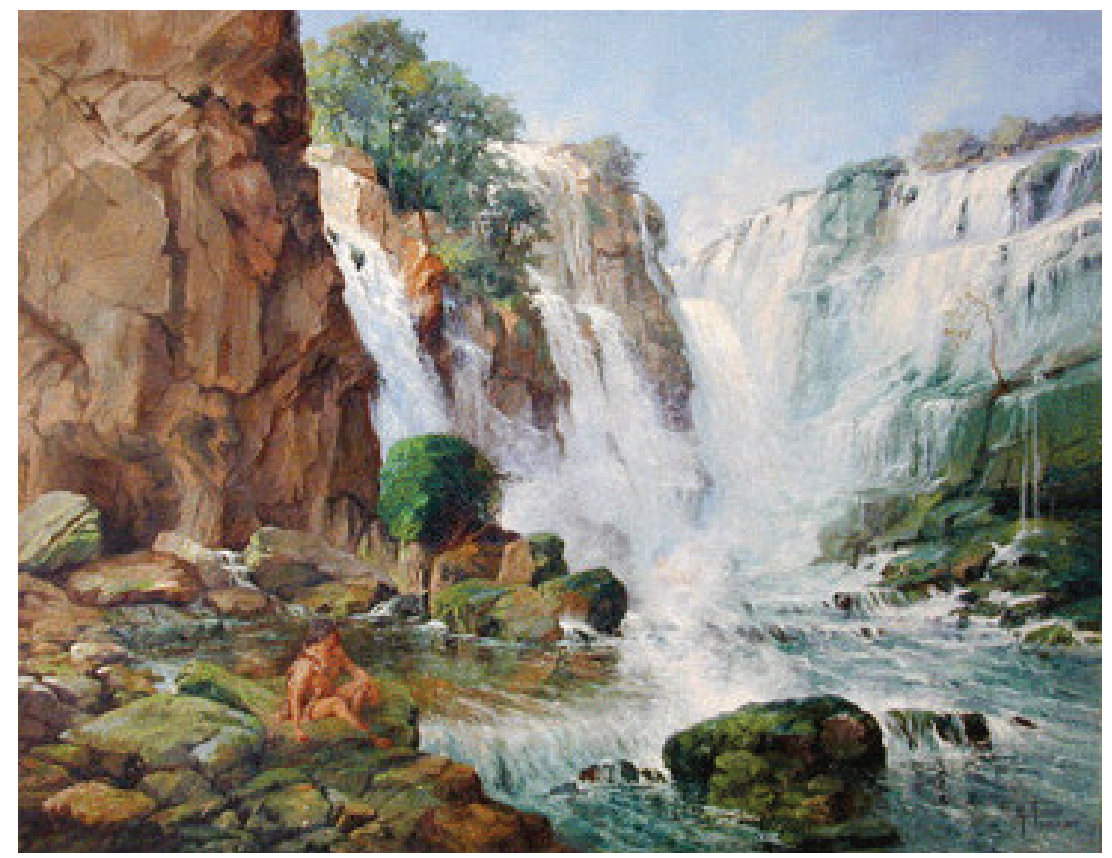

Figura 3: PARREIRAS, Antonio (1860-1937). - Cataratas do Iguaçu, 1920. Óleo sobre tela. 200 x $250 \mathrm{~cm}$. Coleção Palácio Iguaçu.

Fonte: PINTORES da Paisagem Paranaense, 2005, p. 164.

As "Vozes das águas" são apresentas pela poeta Helena Kolody, no texto de densa significação lírica ao descrever as Cataratas do Iguaçu, marcada pela beleza natural e grandeza do espetáculo no "imenso palco" da natureza: 


\section{CATARATAS DO IGUAÇU}

Num profundo clamor,

Salta no abismo o turbilhão das águas.

Referve na garganta, em convulsões, e espuma, Ergue-se em renda e névoa, que o sol irisa,

No imenso palco escarpado, Esgarçam-se líquidos tules, Há esguias águas dançantes, Nevoeiros de arco-íris.

No abismo do tempo imemorável, Reboa, soturna, a voz das cataratas. (KOLODY, Helena. 1999, p. 160)

As imagens das águas em turbilhão geram contrastes com as formas de renda e névoa irisada pelos raios do sol. São movimentos dançantes das águas e do "abismo do tempo imemorável", em que se privilegia uma memória do mundo e do ressoar das vozes das águas. 


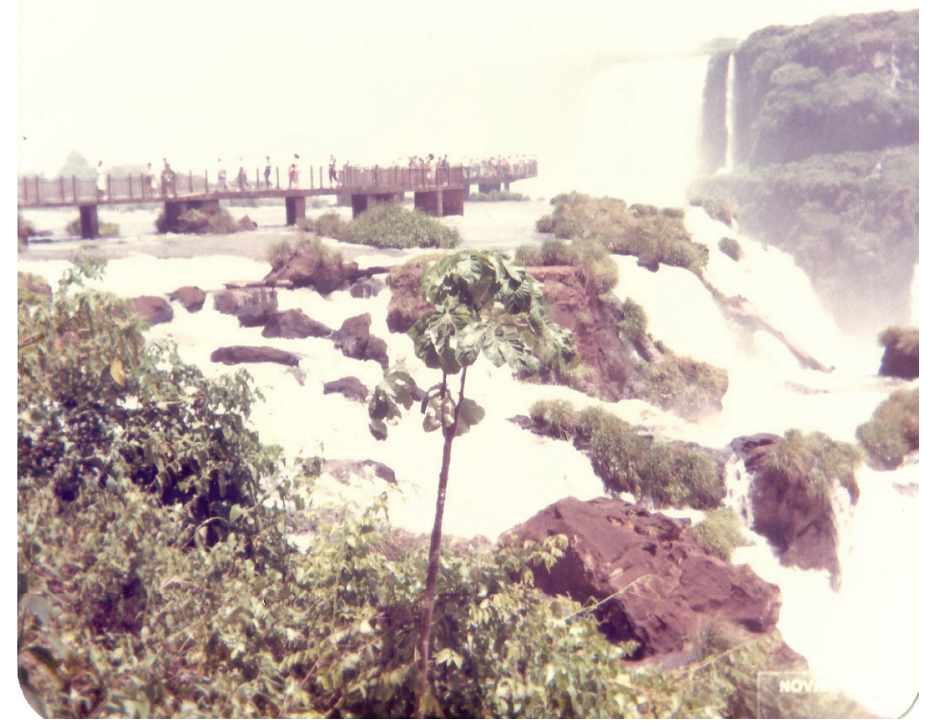

Figura 4: Cataratas do Iguaçu - Nov. 1986.

Fonte: Fotografia de Antonio Donizeti da Cruz.

0 poeta Mario Quintana também tece seu canto de amor às "Cataratas do Iguaçu", no poema que apresenta as imagens dos rios como caminhos mais antigos do mundo, com suas formas e cores, "serpenteiam" os espaços geográficos e não há como limitá-los e sequer parar o curso das águas. 0 questionamento movimenta o poema na indagação do sujeito lírico:

\section{CATARATAS DO IGUAÇU}

Os rios são caminhos

mais antigos

que a redondeza da terra.

Eles descem horizontes

seguem sozinhos no ar. 
E a bela asa em pleno voo, entre o partir e o chegar, sem se importar com fronteiras.

Mas como se há de parar?

(QUINTANA, Mario, 2015)

Os poemas de Mario Quintana e Helena Kolody atestam que não é possível compreender a arte de um determinado período histórico, conforme diz Racionero (1995), sem entender a visão que o homem tem de si mesmo e de sua relação com o mundo no momento em questão. 0 homem deseja distintas coisas em lugares e momentos diferentes. Ele se vê a si mesmo - no universo - de distintas maneiras em momentos e lugares diferentes. Ele se reflete em sua arte. A intuição imaginativa dos problemas que se valorizam em cada época é uma das funções da arte, a qual, ao funcionar por abandono poético à associação de ideias, aos vislumbres, permite captar e expressar o incipiente, ainda formalizar o recém-aceitado. Em nível instrumental, no referente ao material e às ferramentas necessárias para penetrar em um novo campo, é a ciência que vai adiante, de modo que, quando são inventados instrumentos de observação mais precisos, permite-se observar o que as gerações precedentes tiveram que descobrir mediante a imaginação. A olhar atento e valorização da Natureza sempre foram pontos centrais das reflexões e do ofício dos poetas e artistas ao evocar imagens poéticas que mediante a imaginação as combinam e valorizam tais imagens alicerçando-as na força expressiva e na potência de uma poética capaz de dar sentido à vida. Ao buscar a essência da linguagem, os artistas realizam o poder mágico através das palavras poéticas e das imagens enquanto mediação, comunicação e exercício de construção de sentidos, uma vez que elas são manifestações dos entes e seres.

Nas palavras de Javier González (1990), é sempre mediante o universo poético, que o poeta apoia-se nos aspectos lúdicos, rítmicos e imaginários da linguagem, uma vez que a função poética funciona como um vetor constitutivo da natureza humana. É pela palavra que 
o homem se coloca no plano expressivo superior a não significação da ordem natural, pois ela, enquanto núcleo de dispersão e convergência, é capaz de nomear o mundo (GONZÁLEZ, 1990, p. 152-153). Nesse sentido, o trabalho do poeta, artista, se estabelece frente aos meios de fixação e dispersão de sentido, ou seja, como uma construção modular e jogo de palavras que têm por finalidade projetar um grande número de significações, em que o escritor descobre e constrói o mundo utilizando a palavra enquanto instrumento - como bem afirma González - "capaz de conter a surpreendente variedade do real", isto é, ele sabe que o uso da linguagem abre múltiplos espaços de "comunicação e de nominação dos objetos", com bem afirma Gonzáles (1990, p. 156-157).

\section{Sete Quedas: lembrar para não esquecer}

Uma das tarefas primordiais do poeta está na busca de uma elaboração que possibilita representar as coisas e o mundo por das formas simbólicas, uma vez que é mediante a imaginação que se constrói uma poética alicerçada um mundo de sentidos que se interligam à "memória ontogenética", isto é, todo o (re)criar "remete à criação artística e à fruição estética da obra de arte" (MANCIA, 1990, p. 155-159. Grifo do autor). Sendo assim, Mancia observa que ao criar, o artista percorre "todas as etapas do processo que o levou a construir o seu mundo interno", no sentido de recriar objetos que correspondem ao "seu mundo 'ideal' ou 'sublime', aos quais confere uma nova disposição espaço-temporal” (p. 167. Grifo do autor).

Recordar é elemento inerente ao fazer poético e pictórico enquanto registros e arquivos centrados no poder das rememorações e a maneira como o poeta e artistas organizarem os textos, direcionando-os ao tempo e às configurações de imagens que trazem certa valorização da natureza e também os registros de nostalgia e sentimento melancólico em relação a não preservação da natureza, em que o espetáculo do mundo e as paisagens naturais 
precisam ser (re)apresentados de forma a apontar para o esforço de valorização e de uma atenção cada vez maior, Como diz o filósofo Gaston Bachelard, o sonhador inflamado conjuga o que vê ao já visto, ou seja, conhece perfeitamente a associação entre imaginação e memória (1989b, p. 19).

Assim, fundamentando-se em Bachelard, pode-se dizer que os poetas e os artistas, em geral, realizam um fazer poético organizado no mundo das imagens e na rememoração das coisas mais singelas, que despertam para as imagens mais ternas e para as belezas naturais, que semelhante às obras de arte existem para ser contempladas, decodificadas, dialogadas, testemunhadas e perpetuada. Nesse sentido, os poemas, imagens, pinturas e fotografias das Belezas naturais do Paraná, ficam marcados no tempo e a na memória e são forças mediadoras e potências capazes de interligar os fatos, as pessoas e suas ações e as coisas do mundo para que não se perca a memória e para uma maior valorização da natureza, como a projeção da pintura do artista Alfredo Andersen (1860-1935), intitulada Sete Quedas, pintada em 1904 em que visualiza-se o conjunto dos Saltos das Sete Quedas:

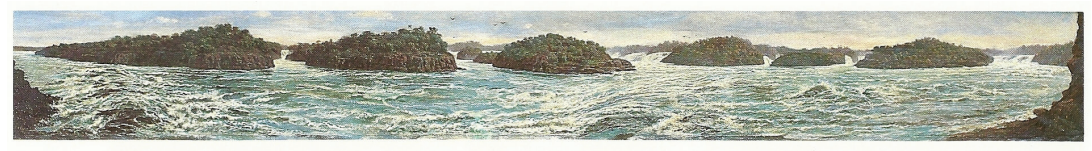

Figura 5: ANDERSEN, Alfredo (1860-1936). - Sete Quedas. Óleo sobre tela. 41 x $322 \mathrm{~cm}$. Coleção Palácio Iguaçu. Coleção Orlando Villela Bittencourt.

Fonte: PINTORES da Paisagem Paranaense, 2505, p. 159.

O poema "Adeus a Sete Quedas", de Carlos Drummond de Andrade, publicado no Jornal do Brasil, de nove de setembro de 1982, é um réquiem às Sete Quedas, e traz duas epígrafes: "Sete damas por mim passaram, / E todas sete me beijaram." de Alphonsus de Guimaraens, e "Aqui outrora retumbaram hinos." de Raimundo Correia. Note-se a forte crítica social do poeta Drummond: 


\section{Adeus a Sete Quedas}

Sete damas por mim passaram,

E todas sete me beijaram.

Alphonsus de Guimaraens

Aqui outrora retumbaram hinos.

Raimundo Correia

Sete quedas por mim passaram, e todas sete se esvaíram.

Cessa o estrondo das cachoeiras, e com ele a memória dos índios, pulverizada, já não desperta o mínimo arrepio.

Aos mortos espanhóis, aos mortos bandeirantes, aos apagados fogos

de Ciudad Real de Guaira vão juntar-se

os sete fantasmas das águas assassinadas

por mão do homem, dono do planeta.

Aqui outrora retumbaram vozes

da natureza imaginosa, fértil

em teatrais encenações de sonhos

aos homens ofertadas sem contrato.

Uma beleza-em-si, fantástico desenho

corporizado em cachões e bulcões de aéreo contorno

mostrava-se, despia-se, doava-se

em livre coito à humana vista extasiada.

Toda a arquitetura, toda a engenharia

de remotos egípcios e assírios

em vão ousaria criar tal monumento.

E desfaz-se

por ingrata intervenção de tecnocratas.

Aqui sete visões, sete esculturas

de líquido perfil

dissolvem-se entre cálculos computadorizados

de um país que vai deixando de ser humano

para tornar-se empresa gélida, mais nada. 
Faz-se do movimento uma represa, da agitação faz-se um silêncio empresarial, de hidrelétrico projeto. Vamos oferecer todo o conforto que luz e força tarifadas geram à custa de outro bem que não tem preço nem resgate, empobrecendo a vida na feroz ilusão de enriquecê-la.

Sete boiadas de água, sete touros brancos, de bilhões de touros brancos integrados, afundam-se em lagoa, e no vazio que forma alguma ocupará, que resta senão da natureza a dor sem gesto, a calada censura e a maldição que o tempo irá trazendo?

Vinde povos estranhos, vinde irmãos brasileiros de todos os semblantes, vinde ver e guardar não mais a obra de arte natural hoje cartão-postal a cores, melancólico, mas seu espectro ainda rorejante de irisadas pérolas de espuma e raiva, passando, circunvoando, entre pontes pênseis destruídas e o inútil pranto das coisas, sem acordar nenhum remorso, nenhuma culpa ardente e confessada. ("Assumimos a responsabilidade! Estamos construindo o Brasil grande!") E patati patati patatá...

Sete quedas por nós passaram, e não soubemos, ah, não soubemos amá-las, e todas sete foram mortas, e todas sete somem no ar, sete fantasmas, sete crimes dos vivos golpeando a vida que nunca mais renascerá.

(ANDRADE, Carlos Drummond de. Jornal do Brasil, Caderno B, 09 set. 1982. In: Drummond: 100 anos. 2015) 
No poema, Carlos Drummond de Andrade manifesta sua inconformidade em relação à destruição do Salto de Sete Quedas - enquanto patrimônio natural do Brasil e da humanidade - por causa da construção da hidrelétrica de Itaipu. 0 eu lírico relembra os mortos da Conquista e dos Bandeirantes e conclama se juntarem a eles "os sete fantasmas das águas assassinadas / por mão do homem, dono do planeta" e tece um panorama do quadro real da história e alude à arquitetura engenhosa da natureza e, por outro lado, aponta para a "destruição" das Sete Quedas pela intervenção de tecnocratas. E conclama a todos para ver pela última vez os Saltos das Sete Quedas e guardá-la para sempre na memória e em cartões postais, mas sem remorso, uma vez que todos "estamos construindo o Brasil grande!". E na última estrofe a triste constatação de que elas passaram, foram destruídas pela falta de amor. Crime, em número de sete, que golpeia a vida que jamais renascerá, tal como afirma o sujeito da enunciação. 


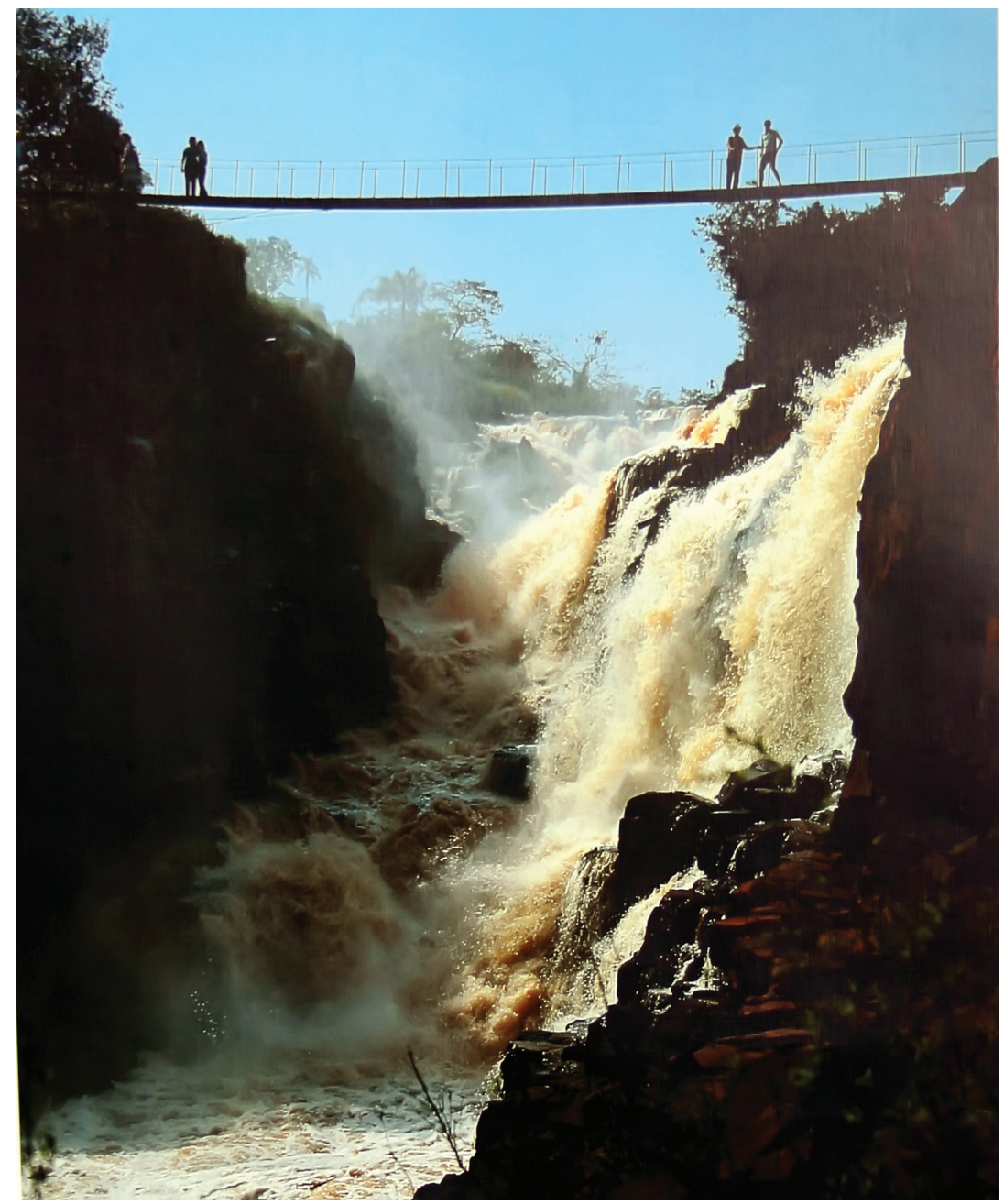

Figura 6: Sete Quedas

Fonte: Foto (Crédito e Cortesia) - Arquivo do Jornal $O$ Presente. Sete Quedas. Marechal Cândido Rondon - PR

O Salto de Sete Quedas também denominado Salto Guaíra (Saltos del Guairá, em castelhano) foi a maior cachoeira do mundo em volume de água, até o seu desaparecimento com a formação do lago da Usina hidrelétrica de Itaipu. Sete Quedas, apesar do nome, eram formadas por dezenove saltos principais, sendo agrupadas em sete grupos de quedas. 
Em relação à Memória, o poeta e crítico Octavio Paz afirma que os poetas têm sido a memória de seus povos, pois "cada poeta é uma pulsão no rio da tradição, um momento da linguagem. Às vezes os poetas negam sua tradição mas só para inventar outra" (1993, p. 109). A invenção lírica se projeta do presente para o futuro. 0 poeta é ciente de sua tarefa: ser elo da cadeia, uma ponte entre o ontem e 0 amanhã. Entretanto, no findar do século XX, ele "descobre que essa ponte está suspensa entre dois abismos: o do passado que se afasta e o do futuro que se arrebenta. 0 poeta se sente perdido no tempo" (PAZ, 1993, p. 108-109). Nesse sentido, ao recriar sua experiência, leva avante um passado que é um futuro. 0 tempo possui uma direção, um sentido, ou seja, "ele deixa de ser medida abstrata e retorna ao que é: concretude e dotado de direção. 0 tempo é um constante transcender" (PAZ, 1982, p. 69).

A função essencial do tempo na estruturação da imagem do mundo reside, conforme Octavio Paz, no fato de que o homem, dotado de uma direção e apontando para um fim, faz parte de um processo intencional (1993, p. 97). Os atos e as palavras dos homens são feitos de tempo. Assim, a cronologia está fundamentada na própria crítica. Já a poesia é tempo revelado, isto é, o enigma do mundo que se transforma em "enigmática transparência". 0 poeta diz o que diz o tempo, até quando o contradiz, pois ele é capaz de nomear o transcorrer, e ainda, "torna palavra a sucessão" (PAZ, 1993, p. 98).

Do tempo revelado, das lembranças e esquecimento de que fazem parte a MEMÓRIA, o poeta é o elo que mediante o processo intencional faz com que as palavras, as imagens poéticas, bem como todas as formas de (re)apresentações da vida e da natureza se convertam em uma grande construção individual e coletiva de preservação da memória:

No "canto" do poeta, os flashes que captam momentos únicos e também nas pinceladas dos artistas, o registro de um tempo marcado pelas lembranças e tecidos nos tênues fios da memória, tal como as passagens do poema "Réquiem para as Sete Quedas", do poeta, ensaísta e escritor João Manuel Simões: 


\section{Réquiem para as Sete Quedas}

Sete quedas, Sete Quedas

(eram sete ou eram mais?)

sete templos liquefeitos, capelas e catedrais, sete cascatas de luz, sete líquidos vitrais, sete sonatas etéreas, sete orfeões, sete corais, sete cantos camonianos, sete poemas minerais, (os versos são alva espuma, as rimas puros cristais) sete quedas, sete quedas que não se levantam mais.

Sete dores, sete mortes, sete afiados punhais, sete gemidos de angústia, [...]

Sete véus, sete grinaldas, sete sonhos nupciais que as sete noivas sonhavam, (sonhos tecidos com fios argênteos de sol e luar). [...] Sete Quedas, Sete Quedas, em tempo de nunca mais, sete mortalhas escondem vossos restos imortais de noivas que se tornaram dos altos deuses vestais. [...] Quando voltarão à vida as sete noivas fatais? Pergunto à brisa que canta na terra dos pinheirais [...] Sete Quedas, Sete Quedas, em vão as invoco, em vão: elas jazem soterradas 
na mais profunda solidão.

[...]

(Sete Quedas, Sete Quedas, noite no meu coração!)

Sete Quedas, Sete Quedas, (eram sete ou eram mais?) Eram sete, sete apenas mas na saudade são mais. (SIMÕES, João Manuel, 1982, p. 9-21)

Os versos do poema de João Manuel Simões, além da crítica social a que se refere o sujeito da enunciação, registra a preocupação do eu lírico ao constatar o desaparecimento das Sete Quedas, cujo canto transforma-se em réquiem, tendo em vista a perda da beleza natural que o Estado do Paraná, o Brasil e o mundo perderam ao dar lugar à construção da hidrelétrica de Itaipu. No texto mostra a força da memória que tem o poder de ativar ou reter as coisas e apontando para a necessidade de se preservar a natureza. Recordar as Sete Quedas é um fator imprescindível que movimenta as aspirações e sentimentos do sujeito poético, pois no momento da recordação o eu lírico rememora, com saudade e erguendo sua voz lembrar a todos da atenção que é preciso ter para com a valorização da natureza. Assim, o texto é uma alerta para que não ocorra destruição das belezas naturais.

As imagens das Sete Quedas e das Cataratas do Iguaçu fornecem múltiplas categorias de percepção de beleza que ficou desaparecida no espaço geográfico e na perda da imagem repleta de beleza e encantamento das manifestações dos Saltos das Sete Quedas, imagens instauram lembrança e um sentimento de tristeza em saber ficaram submergidos em prol do "progresso". Há toda uma valorização das imagens que ficam marcadas nas lembranças das paisagens naturais das Sete Quedas, em que as operacionalizações dos poetas, artistas, que as relembram apontam para as reconstruções de registros e acontecimentos passados. Os olhares e os textos dos escritores e artistas que se voltam para as 
rememorações vividas e registradas que acentuam o poder das imagens e seu poder de simbolização.

\section{REFERÊNCIAS BIBLIOGRÁFICAS}

ANDRADE, Carlos Drummond de. "Adeus a Sete Quedas". Jornal do Brasil, Caderno B, 09 set. 1982. In: Drummond: 100 anos. Disponível em: http://www.algumapoesia.com.br/ drummond/drummond30.htm Acesso em 9 mar 2015.

BACHELARD, Gaston. A água e os sonhos: ensaios sobre a imaginação da matéria.Trad. Antonio de Padua Danesi. São Paulo: Martins fontes, 1989a.

BACHELARD, Gaston. A chama de uma vela. Rio de Janeiro: Bertrand Brasil, 1989b.

BACHELARD, Gaston. A poética do espaço. São Paulo: Martins Fontes, 1993.

CABEZA DE VACA, Álvar Núñez. Naufrágios \& Comentários. Trad. de Jurandir Soares dos Santos. Porto Alegre: L\&PM, 2009 (1. ed. em espanhol 1542).

CATARATAS do Iguaçu - Uma das sete maravilhas da natureza. Disponível em: http://www.fozdoiguacudestinodomundo. com.br/atrativos/cataratas-do-iguacu Acesso em 09 mar. 2015.

CAMPANA, Fábio. Paraíso em chama. Curitiba: Travessa dos editores, 2013. 
DAVALLON, Jean. A imagem, uma arte da memória? In: Papel da memória / Pierre Achard. [et al.]; tradução e introdução de José Horta Nunes. Campinas, SP: Pontes, 1999.

DURAND, Gilbert. A imaginação simbólica. Lisboa: Edições 70, 1995.

DURAND, Gilbert. Campos do imaginário. Textos reunidos por Danièle Chauvin. Trad. Maria João Batalha Reis. Lisboa: Instituto Piaget, 2003.

DURAND, Gilbert. As estruturas antropológicas do imaginário: introdução à arquetipologia geral. Trad. Hélder Godinho. São Paulo: Martins Fontes, 1997 (Ensino Superior).

GONZALES, Javier. El cuerpo y la letra: la cosmología poética de Octavio Paz. México - Madrid - Buenos Aires: Fondo de Cultura Económica, 1990.

KOLODY, Helena. "Cataratas do Iguaçu”. In: Viagem no espelho. 5. ed. Curitiba: Editora da UFPR, 1999.

MANCIA, Mauro. No olhar de Narciso: ensaios sobre a memória, o afecto e a criatividade. Lisboa: Escher, 1990.

PAPEL da memória / Pierre Achard. [et al.]; tradução e introdução de José Horta Nunes. Campinas, SP: Pontes, 1999.

PAZ, Octavio. $O$ arco e a lira. Trad. Olga Savary. Rio de Janeiro: Nova Fronteira, 1982 (Coleção Logos).

PAZ, Octavio. A outra voz. São Paulo. Siciliano, 1993. 
PAZ, Octavio. Convergências: ensaios sobre arte e literatura. Trad. Moacir Werneck de Castro. Rio de Janeiro: Rocco, 1991.

PIMENTEL, Maurício Ragagnin. Cataratas do Iguaçu: experiências e registros de uma paisagem turística. Porto Alegre: Dissertação (Mestrado) - Universidade Federal do Rio Grande do Sul. Instituto de Geociências. Programa de PósGraduação em Geografia, Porto Alegre, RS, UFRGS/PPGEA, 2010.

PINTORES da Paisagem Paranaense. Edição fac similar. Curitiba: Secretaria de Estado da Cultura: Solar do Rosário, 2005.

QUINTANA, Mario. "Cataratas do Iguaçu”. Disponível em: http://prosapoesiaecia.xpg.uol.com.br/quintanamestres. htm Acesso em 09 mar. 2015).

SIMÕES, João Manuel. Réquiem para Sete Quedas. Curitiba: Lítero-Técnica, 1982. 
